Meta

Journal des traducteurs

Translators' Journal

\title{
The Use of Introspection in the Study of Problems Relating to Interpretation from Japanese to English
}

\section{Ng Bee Chin et Yasuko Obana}

Volume 36, numéro 2-3, juin 1991

URI : https://id.erudit.org/iderudit/002234ar

DOI : https://doi.org/10.7202/002234ar

Aller au sommaire du numéro

Éditeur(s)

Les Presses de l'Université de Montréal

ISSN

0026-0452 (imprimé)

1492-1421 (numérique)

Découvrir la revue

Citer cet article

Chin, N. \& Obana, Y. (1991). The Use of Introspection in the Study of Problems Relating to Interpretation from Japanese to English. Meta, 36(2-3), 367-381. https://doi.org/10.7202/002234ar
Résumé de l'article

On a beaucoup utilisé l'introspection dans l'étude des processus de traduction des langues indo-européennes. La méthode d'introspection a été adaptée dans le but d'observer les méthodes d'interprétation japonais-anglais. Sept sujets de langue maternelle anglaise, ayant des niveaux de compétence variés en interprétation, ont participé à cette recherche. Les résultats démontrent que pour interpréter efficacement il est plus important d'avoir une bonne compréhension du discours et de la structure de la langue d'arrivée qu'une connaissance approfondie du vocabulaire. Cela est encore plus important quand le sujet de l'interprétation nécessite l'utilisation du japonais formel. Comme le japonais est une langue caractérisée par l'utilisation de différents styles et registres pour différentes occasions, les résultats de cette étude semblent indiquer que les étudiants interprètes auraient intérêt à se familiariser davantage avec le japonais formel. 


\title{
THE USE OF INTROSPECTION IN THE STUDY OF PROBLEMS RELATING TO INTERPRETATION FROM JAPANESE TO ENGLISH
}

\author{
NG BEE CHIN \\ Key Centre For Asian Languages and Studies \\ University of Queensland, Australia \\ YASUKO OBANA \\ Dept of Japanese and Chinese Studies \\ University of Queensland, Australia
}

FÉSUMÉ

On a beaucoup utilisé l' introspection dans l'étude des processus de traduction des langues indo-européennes. La méthode d'introspection a été adaptée dans le but d'observer les méthodes d'interprétation japonais-anglais. Sept sujets de langue maternelle anglaise, ayant des niveaux de compétence variés en interprétation, ont participé à cette recherche. Les résultats démontrent que pour interpréter efficacement il est plus important d"avoir une bonne compréhension du discours et de la structure de la langue d'arrivée qu' une connaissance approfondie du vocabulaire. Cela est encore plus important quand le sujet de l'interprétation nécessite l'utilisation du japonais formel. Comme le japonais est une langue caractérisée par l'utilisation de différents styles et registres pour différentes occasions, les résultats de cette étude semblent indiquer que les étudiants interprètes auraient intérêt à se familiariser davantage avec le japonais formel.

\section{ABSTRACT}

Introspection has been used widely to study translation processes in Indo-Europeon languages. In this study, the method of introspection was adapted to study interpretation processes in Japanese-English interpretation. Seven native speakers of English with varying levels of competence in Japanese-English interpretation skills took part in this study. The results indicate that rather than vocabulary, a better knowledge of argument and structure of the target language is essential for proficient interpreting. This is especially crucial when the topic of interpretation calls for the use of formal Japanese, as in the case of this study. As Japanese is a language which is characterized by the use of different registers and styles for different occasions, the findings of this study suggest that in the context of conference interpreting, student interpreters could benefit from increased exposure to the use of formal Japanese.

Translation and interpretation are basically very similar in that they both aim at reexpressing in one language, a message initially worded in another. However, unlike translators, interpreters have to work under extreme time pressure. The cognitive processes during these few seconds and minutes have been an enigma for cognitive researchers in language processing for a long time. As Gerver (1976) pointed out, unfortunately the issue is as complex as it is fascinating and, because of the complexities, there has not 
been much research in this area. An overview of research on conference interpretation conducted by Gile (1988a) highlighted the lack of empirical research in this area. The problem of paucity of research in non Indo-European languages, for example, Mandarin Chinese and Japanese are even more acute. Even though this point may seem contentious, it could be the case that students learning to translate or interpret in languages that are historically unrelated would find the task more difficult than students learning to translate or interpret languages which are historically more related. Several researchers have pointed out problems which are specific to Japanese (Gile 1988b; Katagiri 1988; Hara 1988). These researchers argued that some concepts, syntactic patterns and sociolinguistic rules are specific to Japanese and are therefore untranslatable. If we accept these language specific problems as psychologically real, then we would expect interpreters to adopt particular sets of strategies to overcome these problems.

So far, there are more questions than there are answers for. The lack of an established body of research has precluded the possibility of setting up specific hypotheses. Hence, this pilot study was conducted with these questions in mind:

- what are the specific problems relevant to Japanese?

- what kind of cognitive processing operations do the students engage in when they interpret from one language to another?

- what similarities are there in processing across different interpreters? Are there any individual differences?

- Is the use of particular processing strategies related to the quality of the interpretation?

\section{METHOD}

To investigate these questions, a study using verbal data report collection was used. (There are several types of verbal data collection, the details of which can be found in Faerch and Kasper (1986) and Ericsson and Simon (1980). In this method, subjects are advised to verbalise their thoughts as they are processing the translation exercise. With the introspective method concurrent verbalizations are made while the relevant information is still available from short-term memory. This is distinguished from another method of verbal data collection called retrospection, which requires subjects to assess and evaluate their performance after the experimental tasks. In this study, these two methods were used to complement each other.

The task involved sentence by sentence interpretation of a speech about the role of mass communication from Japanese to English. The speech consisted of thirteen sentences. The experimenters are fully aware that the experimental condition of sentence-bysentence interpretation is contrived, but for an initial study, it was decided that other variables like note-taking ability and long term memory problems be excluded from the study.

Firstly, subjects were given the relevant instructions for the introspection task, i.e. to verbalise their thoughts. They were then given some practice in verbalizing prior to the experiment. Secondly, the subjects were played a sentence of the text which they had to interpret into English as quickly as possible. The sentences varied between 30 to $45 \mathrm{sec}$ onds in length. Following that, they were encouraged to talk about the problems associated with interpreting the text. They were also told to comment on their planning process. Apart from the usual encouragement to keep them talking, the experimenters tried to keep their input as limited as possible. When necessary, the subjects were given a second chance at interpreting the sentence, (however, only the first interpretation was taken into account when assessing the product, the second interpretation was used as a reference to study the effect of coaching on lexical items on interpretation). On completion of the 
task, (which lasted for approximately an hour), the subjects were asked to provide insights to their problems encountered in the interpretation process.

This method is arguably difficult to achieve with a task involving audio stimulus instead of the visual one'. However, there is some justification for the need to adopt audio stimulus especially for languages like Japanese and Chinese. Japanese and Chinese are languages which are based on ideographic orthography, (in the case of Japanese it is a mixture of ideographic system and the phonetic system). Hence for these two languages, spoken competence and written competence or ability to decode written text are often two separate levels of skills. It has been reported that non-native speakers of Japanese who are normally fluent in spoken Japanese are hampered with decoding problems in translation tasks. Thus, using interpretation as a medium can serve to overcome the problem of decoding difficulty.

\section{SUBJECTS}

Seven people took part in this study. Six were students who are enrolled in courses in the Japanese and Chinese Studies Department in the University of Queensland. Two of them were still learning Japanese at the third year undergraduate level. Two were from the first year of their interpreting and translating $(\mathrm{I} / \mathrm{T})$ training programme and two were in the second or final year of the $\mathrm{I} / \mathrm{T}$ training programme. For the purpose of comparison, we also decided to include an informant who graduated from the $\mathrm{I} / \mathrm{T}$ programme and who is currently working part-time as an interpreter.

\section{RESULTS AND DISCUSSION}

The results were first transcribed and problems of interpretation were coded according to a series of categories. Assessment of the quality of interpretation was made by a native speaker of Japanese who is also a competent speaker of English. The help of an experienced interpreter was also enlisted to assess the interpretation.

The process of interpretation can be defined as a communication act involving an intermediary, that is, the interpreter. Garcia-Landa (1978, cited in Gile 1988a) reported that in professional interpretation there is a thirty percent information loss rate. Hence, it is not surprising that the most apparent problem is that of information loss through content distortion. Before discussing content distortion, it is necessary to clearly define certain terminologies which have been commonly used in the field but without a clear indication of what they mean.

Content is defined as the denotative meaning or semantic components encoded by the speaker. Content does not include other extralinguistic parameters governed by pragmatics or shared information.

Apart from content, another important element is that of argument. Argument refers to the way in which the content is organised to achieve the effect intended by the speaker. The development of an argument can generally be located at the first level of syntactic analysis. In English, examples of argument can be traced in structures such as If..., then... or else..., In contrast to..., As a result of ..., therefore..., and Despite..., etc. They can also be referred to as framing structures.

To a great extent, an interpreter's skill in presenting an argument is highly correlated to his ability in the logical segmentation of the speaker's information input. Furthermore, sensitivity to the situational pragmatics is also an important criterion of argument. Situational pragmatics refer to factors in the communication act such as:

- who are the recipients of the message?

- what is the speaker's stance in the issue under discussion?

- the speaker's attitude etc. 
Both content and argument are integral components of a message. At this point, it is necessary to point out that there seems to be some confusion over the definition of the term message. So far, in the field of interpretation and translation research message has been used without clear definition, thereby giving rise to much ambiguity. In other instances Gile (1988c), proposes that the term message has been used to refer only to the content of a communication act with other extralinguistic parameters deemed as falling outside the communication act. Pergnier (1978) distinguishes message meaning from linguistic meaning. Pergnier defines message meaning as the speaker's intended meaning which is heavily dependent on context. Schweda-Nicholson (1987), also emphasizes the role of extralinguistic aspects in interpretation. Others, like Seleskovitch ${ }^{2}$ (1976) argued that meaning or message is a process which is language independent ${ }^{3}$.

The approach of this study takes the stance that the message of a communication act, including that of interpretation, comprises both content and argument. It is, therefore, our contention that extralinguistic factors as well as linguistic components form an important and integral part of the message.

The discussion will focus on various aspects of content and argument which lead to either success or failure in the interpretation task. It has to be emphasised that we do not deny the importance of other factors, such as background knowledge, good long and short-term memory and note-taking ability in interpretation. However this study will focus its attention on the more language related problems of interpretation.

The content of a message is considered as distorted, if in interpreting, significant parts of the message are either omitted or altered, thereby resulting in a different presentation of the speaker's intention as shown by the interpretation of the following example:

1. Sentence No. $2^{4}$ (see Appendix 1)

This is because mass communications always aim at attracting the most number of people by appealing to their curiosity.

Interpretation by student $D$ for sentence No. 2

This is due to the fact there are so many different types of mass communications, and through the interest of the people... aims to interest, go through... things that would interest the people

$D$, seems to have understood the message of some relation between mass communications and people in general, and grasped the structure as well as the argument. However, this informant failed to interpret the aim of mass communication in relation to people in general which is the main theme of this sentence ${ }^{5}$.

Extreme distortion can also happen, in which case, the speaker's message is totally obscured. In such an instance, the communication act can be considered to have completely broken down as in the next example.

\section{Sentence No. 9}

Even people who criticise and struggle against these inferior types of entertainment through lectures and theses may also happen to be adversely affected by amusements which have successfully sugar-coated some intentions, e.g. those which drive people into violence and crime.

Interpretation by student $\mathrm{C}$ for sentence No. 9

... there... has been in various speeches and thesis, that which criticised, or have been authors of such which criticised these opinions, and say that there is some thread running through GORAKU which, in the unconscious states that people will succeed by violence or crime. 
Informant $\mathrm{C}$ did not grasp the argument as well as the structures. Even within each clause this informant was not aware of the relation between an agent and its action, i.e. between a subject and a predicate. Thus, the whole interpretation is meaningless, and considered as having extreme distortion in its content.

In analysing content distortion in the results, we found that structure, lexical items and argument were the most important factors which lead to content distortion. By structure we refer to the relation between the syntactic organisation inside the argument. The relation between concepts such as subject, object and complement and so on has to be processed in order to clarify the structure of a sentence. Misinterpreting this can lead to mistakes such as example 3:

\section{Sentence No.8 is structurally organised as:}

$$
\begin{gathered}
\text { Conj }+ \text { Subj }+ \text { Pred + Conj, } \\
\text { If-clause }
\end{gathered}
$$

(In the main clause, the subject is not superficially realised). The subject of the if-clause, i.e. bôryoku o eiyûshisuru sakuhin ga works which worship violence as heroic, is complex as it comprises a phonologically null subject, an object, i.e. bôryoku o violence, and a predicate, i.e. eiyûshisuru worship as hero. The object of the main clause is again complex, i.e. it is a relative clause which comprises an object, in this case, bôryoku o violence and a predicate, in this case kôteisuro approve. The failure to grasp such structural organisations often leads to distortion in the content of the message.

By lexical items, we refer to the misinterpretation of key words ${ }^{6}$ in the text e.g.

4. The subject $C$ misinterpreted the word dôinsuru to lead in sentence 2 as corresponding to the movements of people. Another example of misinterpretation of key words as evident in sentence 9 was due to homophones in Japanese when the same subject misunderstood the word ito intention for thread?.

The results from this study indicate that problems with either structure, argument, lexical items, or the combination of any of these tend to lead to a distortion of the message, or even extreme distortion of the message as the number of problems increases (see Table 1).

\begin{tabular}{|c|c|c|c|c|c|c|c|c|c|}
\hline & \multicolumn{3}{|c|}{ Content } & \multirow{2}{*}{$\begin{array}{l}\text { Misinterpreled } \\
\text { lexical items }\end{array}$} & \multirow{2}{*}{$\begin{array}{l}\text { Structure } \\
\text { not grasped }\end{array}$} & \multicolumn{2}{|c|}{ Arguments } & \multirow[b]{2}{*}{$A \& C$} & \multirow[b]{2}{*}{$\begin{array}{l}\text { Comments } \\
\text { English expression }\end{array}$} \\
\hline & $\begin{array}{l}\text { No } \\
\text { Distorsion }\end{array}$ & Distorsion & $\begin{array}{l}\text { Extreme } \\
\text { Distorsion }\end{array}$ & & & Grasped & $\begin{array}{l}\text { Not } \\
\text { grasped }\end{array}$ & & \\
\hline 1 & $A B C D$ & E & & & & $A B C D$ & & $A B C D$ & $\mathrm{CE}$ \\
\hline 2 & $A B E$ & D & & $\mathrm{CE}$ & BC & ABDE & c & $\mathrm{AB}$ & \\
\hline 3 & $A B C$ & DE & & & D & $\mathrm{ABC}$ & $\mathrm{DE}$ & $A B C$ & DE \\
\hline 4 & $A B E$ & $\mathrm{c}$ & D & & D & $\mathrm{BE}$ & $A C D$ & $\mathrm{BE}$ & A \\
\hline 5 & $A B D$ & $\mathrm{CE}$ & & $\mathrm{CE}$ & & ABDE & C & $\mathrm{AB}$ & \\
\hline of & ABCDE & & & & & ABCDE & & $A B C D E$ & $\mathrm{CE}$ \\
\hline 7 & $A B C$ & $E$ & D & E & $\mathrm{CDE}$ & $\mathrm{ABCE}$ & D & $\mathrm{ABC}$ & \\
\hline 8 & $A B$ & CE & D & $c$ & $\mathrm{CD}$ & ABCE & D & A & \\
\hline 9 & & ABDE & c & $C D$ & $\mathrm{ACDE}$ & $\mathrm{AD}$ & BCE & & \\
\hline 10 & $\mathrm{BCD}$ & $A E$ & & & & $\mathrm{ABCDE}$ & & $\mathrm{BCD}$ & \\
\hline
\end{tabular}

Table 1: Analysis of students' interpretations

Difficulties 
From Table 1, we see the correlation between the distortion of content, i.e. a poorquality interpretation, and problems of grasping structure and argument. With the exception of Sentence 6, all the sentences have one or more distortions (including extreme distortions). Out of these nine sentences, six sentences (Nos. 3, 4, 5, 7, 8, and 9), if they have content distortions, show at the same time structure and/or argument problems. Especially, notice that subject D in Sentence 4, 7 and 8, and subject C in Sentence 9 show extreme distortion as a result of not being able to grasp both the structure and argument.

Excluding the example of subject $E$ for Sentence 1, (as the problem there was more to do with the informant's English expression), the results in Table 1 indicate that $75 \%$ of distortion in our data was due to problems involving grasping structure and/or argument.

So far, it is commonly accepted that the knowledge of lexical items is crucial to interpretation. That the degree of lexical knowledge is related to the quality of interpretation is indisputable. However, in the process of the experiment, it was very noticeable that certain subjects, despite being unable to retrieve the meaning of several words in the text, managed to interpret quite competently. Table 1 shows that the interpretation of the informants $\mathrm{A}$ and $\mathrm{B}$ can be considered to be far superior to those of $\mathrm{C}, \mathrm{D}$ and $\mathrm{E}$, and yet, the superiority in their interpretation is not readily matched by the knowledge of more vocabulary. An analysis of the correlation between distortion and failure to retrieve lexical items in Table 2 yields a random pattern; e.g. for Sentence 2 in Table 2, informant A, despite the lack of knowledge of three lexical items, gave a very competent interpretation, but the interpretation of informants $\mathrm{C}$ and $\mathrm{D}$ suffered varying degrees of distortion even though the level of lexical difficulty for them was not as high as for informant $\mathrm{A}$.

Table 2: Lexical items which present difficulties

\begin{tabular}{|c|c|c|c|c|c|c|c|}
\hline Sentence & Kango & Wago & A & B & C & D & $\mathbf{E}$ \\
\hline 2 & $\begin{array}{l}\text { *Kôkishin } \\
\text { *Taishûu } \\
\text { *Dôin(suru) } \\
\text { Saidaitasû }\end{array}$ & $\begin{array}{l}\text { Kamitsuku } \\
\text { Mezashiteiru } \\
\text { aitetoshi }\end{array}$ & 3 & 1 & {$[0]$} & (2) & 4 \\
\hline 3. & $\begin{array}{l}* \text { Teizoku } \\
*_{\text {Goraku }}\end{array}$ & $\begin{array}{l}\text { kotoni } \\
\text { mukerareru }\end{array}$ & 2 & 1 & 1 & (4) & (3) \\
\hline 4. & $\begin{array}{l}\text { Shukumeiteki } \\
{ }^{*} \text { Gorakusei }\end{array}$ & $\begin{array}{l}\text { *torisaru } \\
\text { yokarô }\end{array}$ & 2 & 2 & (2) & [2] & 3 \\
\hline 5. & $\begin{array}{l}\text { (Goraku)hon-i } \\
\text { taishûteki }\end{array}$ & & 0 & 0 & (1) & 2 & (10) \\
\hline \multicolumn{8}{|l|}{ 6. NONE } \\
\hline 7. & $\begin{array}{l}\text { *jinrui-ai } \\
\text { *enshutsu(suru) }^{\text {ensula }}\end{array}$ & $\begin{array}{l}\text { *tsuchikawareru } \\
\text { *uruoi }\end{array}$ & 4 & 2 & 3 & {$[0]$} & (3) \\
\hline 8. & $\begin{array}{l}\text { eiyûshi(suru)* } \\
\text { *kôtei(suru) } \\
\text { sesô }\end{array}$ & haba o kikasu & 4 & 3 & (3) & [2] & (3) \\
\hline 9. & $\begin{array}{l}\text { kôen } \\
\text { ito } \\
\text { *kanka(sareru) }\end{array}$ & *karitateru & (0) & (4) & [3] & (1) & (3) \\
\hline 10. & & moroha & 1 & 0 & 0 & 1 & 2 \\
\hline \multicolumn{3}{|c|}{$\begin{array}{l}\text { Total Number of lexically } \\
\text { difficult items }\end{array}$} & 20 & 17 & 15 & 18 & 28 \\
\hline * key words & () distortion i & $n$ content & xtrem & tortio & conte & & \\
\hline
\end{tabular}


There are also instances in which the informants, despite being coached about the meanings of the lexical items, still failed to convey the proper message effectively. For example, in Table 2, compare informants $A$ and $C$ with $D$ in Sentence 7, A with D in Sentence 8 , and $B$ with $D$ in Sentence 9. In these sentences, all the former informants show more difficulties with lexical items than informant $D$, but in Table 1, D shows extreme distortions in content while the others successfully interpreted those sentences.

One could argue that perhaps it is the failure to retrieve the key words that would make all the difference. In Table 2, the key words which are considered as semantically loaded (marked with an asterisk) were picked out by native Japanese speakers. These words tended to be main verbs and nouns. In Table 3, the relation between knowledge of key words and content distortion is shown. This table indicates that although it is more beneficial to know key words, knowledge or lack of knowledge for key words has a rather weak correlation with content distortion. For example, in spite of the lack of knowledge of all the key words in each sentence, informant A in Sentence 2 and 7, had no distortion in content. Whereas, though informant $C$ in Sentence 2 and informant D in Sentence 7 had no problems with the key words, their interpretations were found to have extreme distortion.

Interestingly, Campbell's (1990) study of Arabic-English translators also reports that knowledge of vocabulary is not as crucial as one would expect.

Table 3: Relation between knowledge of key words \& content distorsion

$\begin{array}{lllll}\begin{array}{l}\text { Sentence } \\ \text { No. }\end{array} & \begin{array}{l}\text { No. of key } \\ \text { words }\end{array} & \text { Distortion } & \begin{array}{l}\text { Extreme } \\ \text { Distortion }\end{array} & \text { No distortion } \\ 2 & 3 & \text { D2 } & \text { CO } & \text { A3, B1, E1 } \\ 3 & 2 & \text { D2, E2 } & & \text { A1. B1, C1 } \\ 4 & 2 & \text { C1 } & \text { D1 } & \text { A1, B0, E1 } \\ 5 & 1 & \text { CO } & & \\ 7 & 4 & \text { E1 } & \text { DO } & \text { A4, B2, C3 } \\ 8 & 2 & \text { C2, E2 } & \text { D1 } & \text { A2, B2 } \\ 9 & 2 & \text { A0, B2, } & \text { C2 } & \\ 10 & \text { D0, E1 } & & \text { B0, C0, D0 }\end{array}$

The possibility of informants $A$ and $B$ having a better background knowledge of the issue was also considered. However, given that the issues raised by the text were so general in nature, it is unlikely that the topic itself would have posed a serious problem for the informants.

Considering the results shown in the above tables, we consequently conclude that content distortion is more closely related to problems with structure and/or argument than to the degree of knowledge of lexical items.

Tables 1,2, and 3 represent the results of five informants. The results of two other informants, the third year undergraduate students, were not included as their language skills were not advanced enough for them to perform the interpretation task. However, 
the performance of one of these informants has left us with an interesting observation. Despite the fact that this informant (subject F) did not know most of the lexical items for Sentence 4, he managed to give the following interpretation:

... furthermore, ... it was people who, ... liking entertainment... And then something about the mass communications..., there is some conclusion about what mass communication does, because people like, or because something likes entertainment...

The argument of this sentence is Because $X$, (therefore) $Y$. (X, $\mathrm{Y}=$ clauses). The informant refers to this as something about mass communications (i.e.X) and there is some conclusion (i.e.Y). We assume that at least he grasped the first frame of the sentence. Though this informant possessed a limited knowledge of vocabulary, and had no skills in note-taking, he managed to grasp the argument of the sentence. In contrast, when the same sentence was interpreted by informants $C$ and $D$, (trained student interpreters with superior language skills), they had content distortion because of their difficulty with grasping argument and/or structure (see Table 1), despite the fact that both $\mathrm{C}$ and $\mathrm{D}$ reported not knowing only two words for the sentence (see Table 2).

The results do not imply that subject $F$ is superior to subjects $C$ and $D$ in interpretion skills. However, we would like to emphasize that F's ability in breaking down a sentence into analysable units could be a valuable basis on which to build interpretation skills. Increasing word awareness is undoubtedly important, but the findings of this study suggest that it is only through ability in analysing the argument and structural input that a student interpreter could arrive at an accurate and efficient interpretation.

Problems with presenting the argument are generally apparent by studying the product, that is, the interpretation data, but problems with lexical items and structure are made apparent through analysis of both the product and the introspection data.

At present, what is evident is that both structural and argument awareness are necessary for good quality interpretation but what remains unclear is the correlation between structural knowledge and argument structuring. Which precedes the other? A post-study attempt to investigate this issue has already been started, and the results will be reported in a forthcoming paper.

An interesting observation is that all the informants, with the exception of $\mathrm{A}$, have a high level of competence in informal Japanese. (By informal Japanese, we mean a conversational language which contains less Sino-Japanese words, less old-fashioned as well as honorific expressions, and more native-Japanese words, compared with formal Japanese).

In other words, most of them can conduct an informal conversation in Japanese fluently. In contrast, informant A is not too fluent in informal Japanese, and yet, this informant gave the best interpretation in the group. Informant $\mathrm{A}$ admitted to having a better aptitude in formal Japanese than in informal Japanese. This insight led us to consider another variable, which is that of register.

A reanalysis of the data indicated that the linguistic problems experienced by the students are closely tied to the academic or formal use of Japanese. Most people are very aware of the degrees of formality encoded in spoken English; the type of language employed in delivering a lecture and that used over a casual dinner conversation are definitely quite distinct. This is even more markedly coded in Japanese.

It is a common misapprehension that spoken language is "less complex". Halliday (1985) demonstrated that spoken English is just as syntactically complex as written English. Degrees of complexity are analysed in terms of clause complexity and levels of subordination. A text count of Japanese spoken on formal occasions, e.g. interviews, conferences and news broadcasts indicated that more than 50 percent of the language 
used involves a high degree of clause complexity and multiple embedding. The following table is drawn from:

(1) a dialogue between two history novelists which focuses on the difference between the Japanese and the Chinese from a historical viewpoint (style: informal)

(2) a story book which is meant for parents to read aloud to their children at the age of 5-8 (colloquial spoken style), and

(3) an interview in which a non-fiction writer replies to questions on the Tian An Men massacre (style: formal).

Table 4: Text counting

$\begin{array}{ccccc}\text { Text No. } & \text { Total no } & \text { Complex } & \begin{array}{c}\text { Types of sentences } \\ \text { Simple }\end{array} & \text { Conjunct } \\ \text { (1) } & 30 & 9 & 15 & 8 \\ (2) & 25 & 10 & 7 & 8 \\ (3) & 11 & 11 & 0 & 6\end{array}$

Simple $=$ only one subject-predicate relation in a clause.

Complex $=$ more than one subject-predicate relation in a clause without a conjunction.

Conjunct $=$ more than one subject-predicate relation in a clause combined with conjunctions; each clause may or may not be complex.

Some sentences comprise both complex units and conjuncts. As pointed out earlier, a significant proportion of the three texts contain sentences which are by definition complex. Text (1), contains the lowest number of complex sentences. An interesting outcome is that although the content of Text (2) is simple i.e. the text uses a lower level of style and vocabulary, very few abstract expressions, and no written style. However, ten out of the twenty-five sentences in Text (2) are complex. As one would expect, increased formality in the context is a direct correlate of an increase in sentence complexity. The analysis of the sentence structures in Text (3), a political discourse, shows that there are no simple sentences - only complex ones.

The implications of the above observation are significant if one takes into consideration the fact that the context of conference interpreting is often more formal and specialised. Hence, while it is true that spoken Japanese is "easier" to understand than written Japanese ${ }^{9}$, depending on the context, the structural differences in formal spoken Japanese can pose considerable difficulty to someone who has had limited exposure to such language.

Apart from sentence structure, the type of vocabulary used in formal Japanese is also significantly different from informal Japanese. As the context becomes more formal, the number of Sino-Japanese noun compounds increases. Kanaoka (1977) reported that in formal contexts, 41.3 percent of the lexical items used are Sino-Japanese noun compounds. This figure is of some concern when one considers the fact that in this study, a greater percentage of lexical difficulties was found to be associated with Sino-Japanese noun compounds. Table 4 indicates the percentage of difficulties students experienced with Sino-Japanese words as compared to native Japanese words. In general, 62 percent of lexical difficulties reported were Sino-Japanese words, and this percentage increased to nearly 70 percent when only the key words were considered. 
Table 5: Comparing Kango and Wago in the text

$\begin{array}{ll} & \begin{array}{l}\text { Percentage of } \\ \text { difficulty }\end{array} \\ \text { Kango (Sino-Japanese) } & 62 \% \\ \text { Wago (native-Japanese) } & 38 \% \\ \text { Kango key words } & 69 \% \\ \text { Wago key words } & 31 \%\end{array}$

Given the fact that Sino-Japanese noun compounds tend to saturate formal spoken Japanese, a good knowledge of such noun compounds is essential to students who aspire to be conference interpreters. The problem is that Sino-Japanese noun compounds can only be effectively acquired in context. Therefore, familiarisation with Sino-Japanese noun compounds entails being exposed to different formal texts, whether spoken or written.

\section{CONCLUSION}

In investigating problems faced by student interpreters, we have noticed that the ability to grasp the structure and argument of the input language is one of the important variables for effective interpretation. While other factors such as background information, note-taking ability, long and short-term memory are also crucial to interpretation, language ability, particularly analytical linguistic skills, has often been ignored. For competent and professional interpreters, this factor is probably negligible. However, the findings of this study indicate that for student interpreters whose language skills are still developing, a heightened awareness of structural relationship could be an advantage in improving interpretation skills, especially for a language like Japanese which is structurally so different from English. This study also suggests that exposure to formal spoken Japanese is essential to students who aspire to be conference interpreters.

Finally, the use of the introspective method has allowed us to gain valuable insights into the problems faced by student interpreters during the short time-span in which interpreting takes place. However, relying on verbal-report data is not without its disadvantages. This particular method is highly dependent on the verbosity of the informants. Hence, the amount of introspective data varies from individual to individual, which sometimes makes comparison across informants difficult. In addition, the cognitive process of interpretation can only be inferred from the data. The method only allows one to hypothesise about the process that takes place. These speculations will hopefully be the topic of another paper.

\section{Appendix 1: Interpretation Text}

1.

\begin{tabular}{lllllllll} 
Inu & ga & hito & \multicolumn{2}{c}{ ni - kamitsuita } & no & dewa & nyûsu ni \\
dog & NOM & person & LOC & bite & NOM & AFF & news & \\
& CM & & & & & & & \\
nara - nai & ga, & hito & ga & inu & ni & kamitsuku to nyôsu \\
become neg & but & person & NOM & dog & LOC & bite & Q news
\end{tabular}


ni naru to iu.

AFF become $Q$ say.

It's said, If a dog bites a person, that would not become news. However, if a person bites a. dog, that would become news

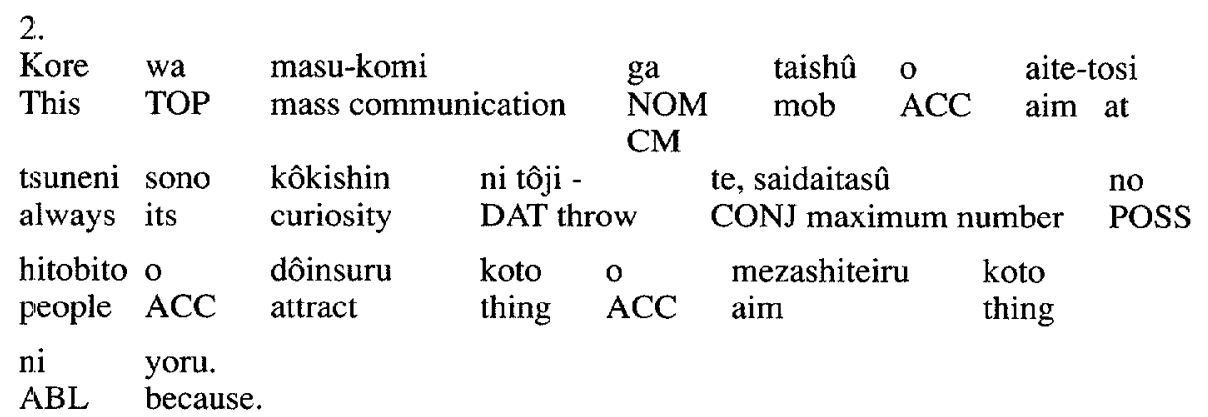

This is because mass communications always aim at attracting the most number of people by appealing to their curiosity.

3.

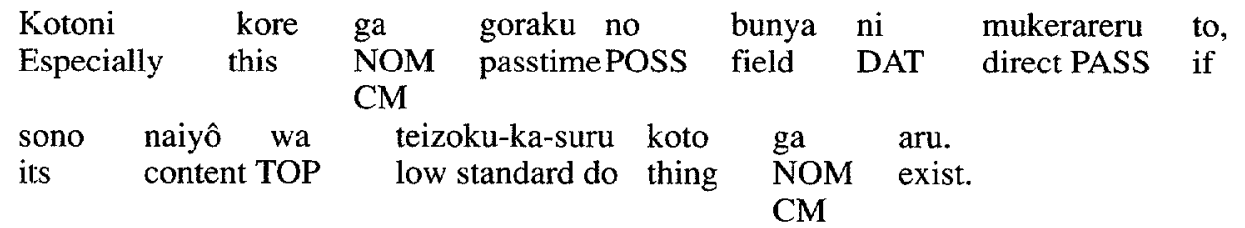

Especially if this is directed towards the field of recreation, it often happens that the content will become inferior.

4.

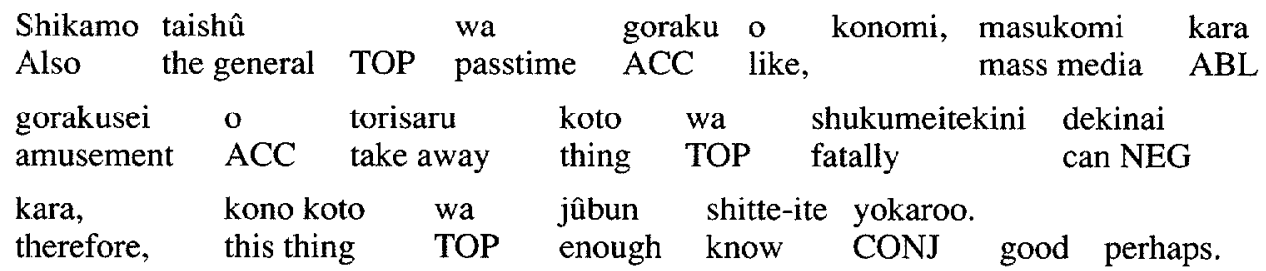

Furthermore, people like entertainment and it is absolutely impossible to take away the amusement nature from mass media. Therefore, it is better to bear this in mind.

5 .

$\begin{array}{lllll}\text { Zasshi dewa, goraku - mono } & \text { ga } & \text { mottomo } & \text { taishûteki-de } \\ \text { Magazine TOP } & \begin{array}{l}\text { amusement } \\ \text { thing }\end{array} & \begin{array}{l}\text { NOM most } \\ \text { CM }\end{array} & \text { popular AFF }\end{array}$

aru - si, shinbun de-mo, goraku hon'i no nyûsu ya to be CONJ newspaper in too, amusement centre POSS news soon

supôtu nyuusu ga yoku yoma - reru.

sports news NOM often read PASS.

$\mathrm{CM}$ 
In magazines, amusement related articles are most popular and even in newspapers amusement-centred news, sports news and so on is often read.

6.

$\begin{array}{llllllll}\text { Eiga } & \text { wa } & \text { goraku } & \text { chûshin-ni } & \text { hattatsu-shite } & \text { kita- } & \text { shi } & \text { rajio } \\ \text { Film } & \text { TOP } & \text { amusement } & \text { centred } & \text { develop come } & \text { PST } & \text { CONJ } & \text { radio } \\ \text { terebi } & \text { de-mo } & \text { goraku } & \text { bangumi } & \text { ga } & \text { hanbun } & \text { ijô } & \text { o } \\ \text { TV } & \text { at too } & \text { amusement } & \text { programme } & \text { NOM } & \text { half } & \text { more than } & \text { ACC }\end{array}$

shimeteiru.

occupy.

Films have developed as the centre of entertainment, and also more than fifty percent of television and radio programmes are occupied by entertainment programmes.

$6 \mathrm{a}$

Goraku no naka niwa nin-gen no shinjô o

amusement POSS among TOP human being POSS emotion ACC

takameru mono mo aru-shi, teika saseru mono mo aru.

raise thing too exist CONJ decrease CAUS thing too exist.

Among the different types of amusements, there are those which elevate one's mind and also those which degenerate/denigrate one's mind.

7.

\begin{tabular}{|c|c|c|c|c|c|c|c|c|}
\hline $\begin{array}{l}\text { Jinrui } \\
\text { human }\end{array}$ & being & $\begin{array}{l}\text { ai } \\
\text { love }\end{array}$ & $\begin{array}{l}\text { o } \\
\text { ACC }\end{array}$ & $\begin{array}{l}\text { tataeru } \\
\text { praise }\end{array}$ & $\begin{array}{l}\text { sugureta } \\
\text { superior }\end{array}$ & $\begin{array}{l}\text { geiju } \\
\text { arts }\end{array}$ & & $\begin{array}{l}\text { akuhin } \\
\text { roduction }\end{array}$ \\
\hline $\begin{array}{l}\circ \\
\mathrm{ACC}\end{array}$ & \multicolumn{2}{|c|}{$\begin{array}{l}\text { goraku } \\
\text { amusement }\end{array}$} & \multicolumn{2}{|c|}{$\begin{array}{l}\text { bangumi } \\
\text { programme }\end{array}$} & $\begin{array}{l}\text { ga } \\
\text { NOM } \\
\text { CM }\end{array}$ & $\begin{array}{l}\text { kyômi } \\
\text { interest }\end{array}$ & $\begin{array}{l}\text { bukaku } \\
\text { deeply }\end{array}$ & $\begin{array}{l}\text { kôkatekini } \\
\text { effectively }\end{array}$ \\
\hline \multicolumn{2}{|c|}{$\begin{array}{l}\text { enshutsusure- } \\
\text { produce }\end{array}$} & $\begin{array}{l}\text { ba, } \\
\text { if }\end{array}$ & $\begin{array}{l}\text { taishû } \\
\text { mob }\end{array}$ & $\begin{array}{l}\text { no } \\
\text { POSS }\end{array}$ & $\begin{array}{l}\text { kokoro } \\
\text { mind }\end{array}$ & $\begin{array}{l}\text { no } \\
\text { POSS }\end{array}$ & $\begin{array}{l}\text { naka } \\
\text { inside }\end{array}$ & $\begin{array}{l}\text { ni } \\
\text { LOC }\end{array}$ \\
\hline $\begin{array}{l}\text { uruoi } \\
\text { taste }\end{array}$ & $\begin{array}{l}\circ \\
\text { ACC }\end{array}$ & $\begin{array}{l}\text { atae, } \\
\text { give }\end{array}$ & $\begin{array}{l}\text { heiwa } \\
\text { peace }\end{array}$ & $\begin{array}{l}\text { o } \\
\text { ACC }\end{array}$ & $\begin{array}{l}\text { nozomu } \\
\text { wish }\end{array}$ & $\begin{array}{l}\text { kokoro } \\
\text { mind }\end{array}$ & $\begin{array}{l}\text { ga } \\
\text { NOM } \\
\text { CM }\end{array}$ & $\begin{array}{l}\text { tsuchikaware- } \\
\text { develop PASS }\end{array}$ \\
\hline
\end{tabular}

te iku-dearoo.

CONJ go be perhaps

If amusement programmes could produce works of art which effectively enhance humanity, they would enrich the mental life of the public and also inspire them to desire peace.

8.

Sore to hantaini bôryoku o eiyûsisuru

it to/ against opposite violence ACC worship as hero

sakuhin ga haba-o-kikasu - yôna koto ga are-ba

products NOM dominate alike thing NOM exist CONJ 


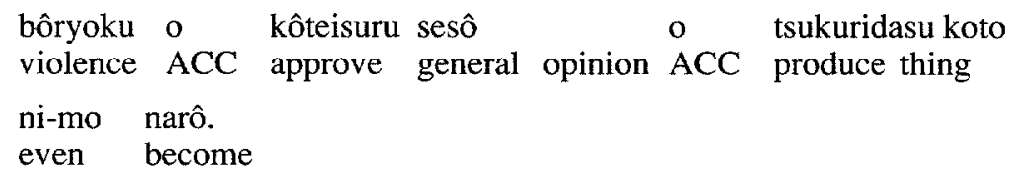

On the other hand, if works which worship violence as heroic become popular, it may result in a general approval of violence.

$8 \mathrm{a}$

\begin{tabular}{|c|c|c|c|c|c|c|}
\hline $\begin{array}{l}\text { Goraku } \\
\text { amusement }\end{array}$ & $\begin{array}{l}\text { ga } \\
\text { NOM } \\
\text { CM }\end{array}$ & $\begin{array}{l}\text { taishû } \\
\text { the public }\end{array}$ & toward & $\begin{array}{l}\text { ni } \\
\text { flatter }\end{array}$ & $\begin{array}{l}\text { kobi } \\
\text { inferior }\end{array}$ & $\begin{array}{l}\text { teizoku } \\
\text { towards }\end{array}$ \\
\hline $\begin{array}{l}\text { hashire- ba, } \\
\text { go ahead CON }\end{array}$ & $\begin{array}{l}\text { taishû } \\
\text { public }\end{array}$ & $\begin{array}{l}\text { no } \\
\text { POSS }\end{array}$ & $\begin{array}{l}\text { shumi } \\
\text { hobby }\end{array}$ & $\begin{array}{l}\text { ya } \\
\text { and so on }\end{array}$ & $\begin{array}{l}\text { kyôyô } \\
\text { culture }\end{array}$ & $\begin{array}{l}\mathrm{o} \\
\mathrm{ACC}\end{array}$ \\
\hline $\begin{array}{l}\text { obiyakasu } \\
\text { threaten }\end{array}$ & $\begin{array}{l}\text { koto ni } \\
\text { thing }\end{array}$ & $\begin{array}{l}\text { naru. } \\
\text { become. }\end{array}$ & & & & \\
\hline
\end{tabular}

If amusement compromises its quality in order to please the public, it will soon become a threat to the hobbies and culture of the people in general.

9.

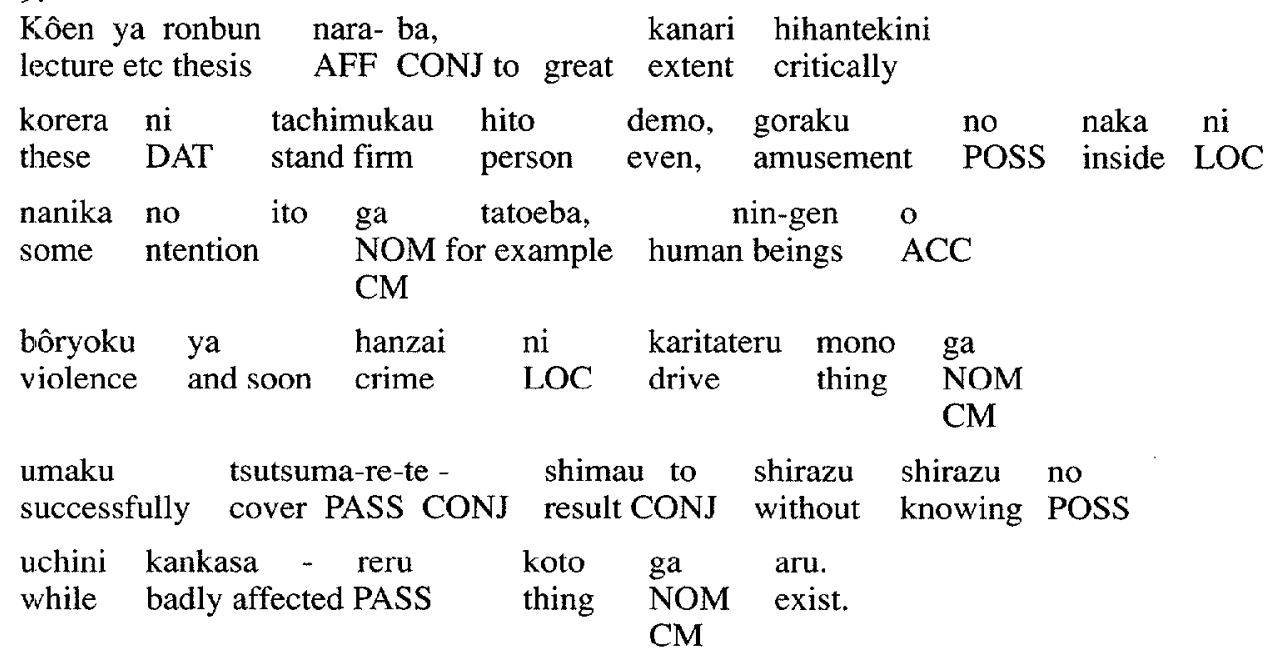

Even people who criticise and struggle against these (inferior types of entertainment) through lectures and thesis may also happen to be adversely affected by amusements which have successfully sugar-coated some intentions e.g., those which drive people into violence and crime.

9 a.

\begin{tabular}{|c|c|c|c|c|c|c|c|}
\hline $\begin{array}{l}\text { Masu- } \\
\text { mass }\end{array}$ & $\begin{array}{l}\text { komi } \\
\text { communication }\end{array}$ & $\begin{array}{l}\text { no } \\
\text { POSS }\end{array}$ & $\begin{array}{l}\text { motsu } \\
\text { possess }\end{array}$ & $\begin{array}{l}\text { mashô- } \\
\text { mystry }\end{array}$ & $\begin{array}{l}\text { meita } \\
\text { trend }\end{array}$ & $\begin{array}{l}\text { mono } \\
\text { thing }\end{array}$ & $\begin{array}{l}\text { ga, } \\
\text { NOM } \\
\text { CM }\end{array}$ \\
\hline $\begin{array}{l}\text { seishônen } \\
\text { the youth }\end{array}$ & $\begin{array}{l}\mathrm{o} \\
\mathrm{ACC}\end{array}$ & $\begin{array}{l}\text { aku } \\
\text { evil }\end{array}$ & $\begin{array}{l}\text { ni } \\
\text { LOC }\end{array}$ & $\begin{array}{l}\text { sasoi, } \\
\text { lure }\end{array}$ & $\begin{array}{l}\text { hanzai } \\
\text { crime }\end{array}$ & $\begin{array}{l}\text { ni } \\
\text { LOC }\end{array}$ & $\begin{array}{l}\text { karitateru } \\
\text { drive }\end{array}$ \\
\hline
\end{tabular}


$\begin{array}{lll}\text { koto mo } & \text { aru. } \\ \text { thing } & \text { too } & \text { exist }\end{array}$

Mass communication seems to possess some mysterious power which lures the youth into evil and drive them to crime.

10.

$\begin{array}{lllllll}\text { Masukomi } & \text { wa } & \text { moroha } & \text { no } & \text { ken } & \text { nimo } & \text { tatoera- reru. } \\ \text { mass media } & \text { TOP } & \text { double-edged } & \text { POSS } & \text { sword too } & \text { compare PASS }\end{array}$

Atsukai kata ni-yottewa doku nimo kusuri nimo

treat way according to poison too medicine too

narunoda.

become.

Mass communication can be compared to a double-edged sword. According to the way it is used, it could be a panacea or a destructive force.

$\begin{array}{cl}\text { Symbols: } & \\ \text { NOM } & \text { nominalizer } \\ \text { NOM CM } & \text { Nominative Case Marker } \\ \text { LOC } & \text { Locative (case marker) } \\ \text { AFF } & \text { Affirmative } \\ \text { Q } & \text { Quotation } \\ \text { TOP } & \text { Topic (marker) } \\ \text { PASS } & \text { Passive } \\ \text { POSS } & \text { Possesive } \\ \text { ACC } & \text { Accusative (case marker) } \\ \text { DAT } & \text { Dative (case marker) } \\ \text { ABL } & \text { Ablative } \\ \text { CONJ } & \text { Conjunction } \\ \text { NEG } & \text { Negative } \\ \text { PST } & \text { Past } \\ \text { CAUS } & \text { Causative (case marker) }\end{array}$

\section{NOTES}

1. Most researchers using verbal protocols for language studies use it in conjunction with translation rather than interpretation (e.g. Krings 1986; Holsher and Mohle 1986 and Zimmermann and Schneider 1986)

2. However, since then she has been continually modifying her argument (see Seleskovitch, 1988).

3. See Jensen (1985) for a critic of Seleskovitch's view.

4. Henceforth, all examples of the sentences can be found in Appendix 1.

5. Example 1 is an excerpt from the interpretation data collected from this study.

6 . The key words were jointly identified by the research informants and the researchers, as those which carry the essential semantic information for the text.

7. Ito is the homophone for both thread and intention in Japanese.

8. The figures after each subject indicate the number of unknown keywords.

9. A text count of various written Japanese texts indicated that more than $70 \%$ of the sentences in the texts were dominated by structures with greater degrees of clausal complexity and subordination. 


\section{BIBLIOGRAPHY}

CAMPBELL, S. (this volume): "Towards a Model of Translation Competence", Meta.

ERICSSON, K.A. and H.A. Simon (1980): "Verbal Reports as data", Psychological Review, 87, pp. $215-251$.

FAERCH, C. and G. KASPER (Eds) (1986): Introspection in Second Language Research, Multilingual Matters, Clevedon.

GERVER, D. (1976): "Empircal Studies of Simultaneous Interpretation: a Review and a Model", Brislin R. (Ed.) Translation, Gardner Press, New York.

GILE, D. (1988a): "An Overview of Conference Interpretation Research and Theory", Proceedings of the 29th Annual Conference, October 12-16 (Seattle), Medford, NJ, Learned Information, pp. 363-372.

GILE, D. (1988b): "Japanese Logic and the Training of Translators", Hammond, D. (Ed.), Languages at Crossroads, Proceedings of the 29th Annual Conference of the American Translators' Association, October 12-16, (Seattle), Medford, NJ, Learned Information, pp. 257-264.

GILE, D. (1988c): “A Lexical Characterization of Translators and Interpreters (Part 1)", JAT Bulletin (No.43).

HALLIDAY, M.A.K. (1985): Spoken and Written Language, Deakin University, Victoria.

H.ARA, F. (1988): "Understanding the Silent Culture of the Japanese", Meta, 33-1, pp. $22-24$

HOLSCHER, A. and D. MOHLE (1987): "Cognitive Plans in Translation", Faerch, C. and Kasper, G. (Eds) Introspection in Second language research.

JENSEN, P.A. (1985): "SI: A Note on Error Typologies and the Possibility of Gaining Insight in Mental Processes", Meta, 30-1.

KANAOKA, T. (1977): "The History of Word Studies", Iwanami - Lectures on Japanese, 9, pp. 373-404, Iwanami publishing company, Japan.

KATAGIRI, Y. (1988): "Some Untranslatable Aspects of the Japanese Language: A General Semantic View", Meta, 33-1, pp. 1-126.

KRINGS, H.P. (1986): "The use of Introspective Data in Translation", Faerch, C. and Kasper G. (Eds) Introspection in Second Language Research.

PERGNIER (1978): "Language Meaning and Message Meaning: Towards a Sociolinguistic Approach to Translation", Gerver, D. and Sinaiko, W.H. (Eds) Language Interpretation and Communication, Plenum Press, New York.

SCHWEDA-NICHOLSON, N. (1987): "Language and Extralinguistic Aspects of Simultaneous Interpretation", Applied Linguistics, 8, p. 2

SELESKOVITCH, D. (1976): "Interpretation: A Psychological Approach to Translating", Richard W. Brislin (Ed.), Translation: Applications and Research, Gardner Press, New York.

SELESKOVITCH, D. (1988): "Technical and Literary Translation: A Unifying View", Translators and Interpreters Mean Business, ASLIB, London.

ZIMMERMANN, R. and K.P. Schneider (1986): "The Collective Learner Tested: Retrospective Evidence for a Model of Lexical Search", Faerch, C. and Kasper, G. (Eds). 